\title{
HUBUNGAN PERUBAHAN CUACA DENGAN INDEKS KECERAHAN MATAHARI, SUHU LINGKUNGAN DAN KELEMBAPAN UDARA DI DESA KARANGANYAR
}

\author{
Azizah Nur Jannah ${ }^{1}$, Sudarti $^{2}$ \\ ${ }^{1,2}$ Program Studi Pendidikan Fisika FKIP Universitas Jember \\ Iazjannah1@gmail.com, ${ }^{2}$ sudarti.@unej.ac.id
}

\begin{abstract}
The weather simulation in Karanganyar Village, entitled the relationship between weather changes and the sun's brightness index, environmental temperature and humidity in Karanganyar Village. In this simulation or research, it discusses changes in sunlight intensity, ambient temperature (T) and humidity (RH) that occur on Sunday, Tuesday, Thursday and Saturday. Apart from conducting a study, it also looks at the relationship between the variables to be studied. Like seeing the relationship between temperature and humidity, the relationship between weather and sunlight intensity. The evaluation is carried out by examining and also comparing the intensity of sunlight, ambient temperature and air flexibility to changes in weather. Research on weather relations uses the survey research method and data collection methods, namely by using research measuring instruments and recording the results of the survey using the BMKG application to obtain accurate data. This study used a BMKG measuring instrument to determine the weather, temperature, sunlight intensity, and humidity for the 4 days. The data obtained is that the brighter the weather and the greater the air temperature, the lower the humidity.
\end{abstract}

Keywords: air temperature, humidity, weather, brightness index, BMKG

Abstrak: Simulasi cuaca di Desa Karanganyar yang berjudul hubungan perubahan cuaca dengan indeks kecerahan matahari, suhu lingkungan dan kelembapan udara di Desa Karanganyar. Pada simulasi atau penelitian ini yaitu membahas mengenai perubahan intensitas cahaya matahari, suhu lingkungan (T) dan kelembapan udara (RH) yang terjadi pada hari Minggu, Selasa, Kamis dan Sabtu. Selain dari melakukan sebuah penelitian juga melihat hubungan antar variabel yang akan di teliti. Seperti melihat hubungan antara suhu dengan kelembapan udaranya, hubungan cuaca dengan intensitas cahaya matahari. Evaluasi yang dilakukan yaitu dengan meneliti dan juga membandingkan intensitas cahaya matahari, suhu lingkungan dan kelempadan udara terhadap perubahan cuacanya. Penelitian hubungan cuaca menggunakan metode penelitian surve dan cara pengumpulan data yaitu dengan menggunakan alat ukur (instrumen) penelitian dan mencatat hasil dari surve yang menggunakan aplikasi BMKG untuk mendapatkan data yang akurat. Penelitian ini menggunakan alat ukur BMKG untuk mengetahui cuaca, suhu, intensitas cahaya matahari, dan 
kelembapan udara pada 4 hari tersebut. Data yang diperoleh yaitu semakin cerah cuacanya dan semakin besar suhu udara maka semakin rendah kelembapan udara.

Kata kunci: suhu udara, kelembapan udara, cuaca, indeks kecerahan, bmkg

Desa Karanganyar Kecamatan Ambulu Kabupaten Jember, secara umum Desa Karanganyar ini memiliki suatu letak yang geografis dan Desa Karanganyar ini terletak pada wilayah dataran yang bisa dibilang cukup luas dan terdapat beberapa area, yaitu area persawahan yang sangat subur terletak di Kecamatan paling selatan dari wilayah Kabupaten Jember. Desa Karanganyar berjarak $12 \mathrm{~km}$ dari garis pantai yang merupakan pulau paling selatan dari wilayah Negara Kesatuan Republik Indonesia. Desa Karanganyar Kecamatan Ambulu memiliki luas wilayah \pm 1.460 Hektar. Desa Karanganyar terletak di ketinggian \pm 18 mdl dari permukaan laut dengan dataran yang menghampar seluas \pm 1.460 Hektar. Desa Karanganyar memiliki keadaan cuaca pada Curah hujan < 2000 Mm setiap tahunnya, Jumlah bulan hujan yaitu terdiri 4 bulan dan Suhu rata - rata di Desa Karanganyar $23-32^{\circ} \mathrm{C}$.

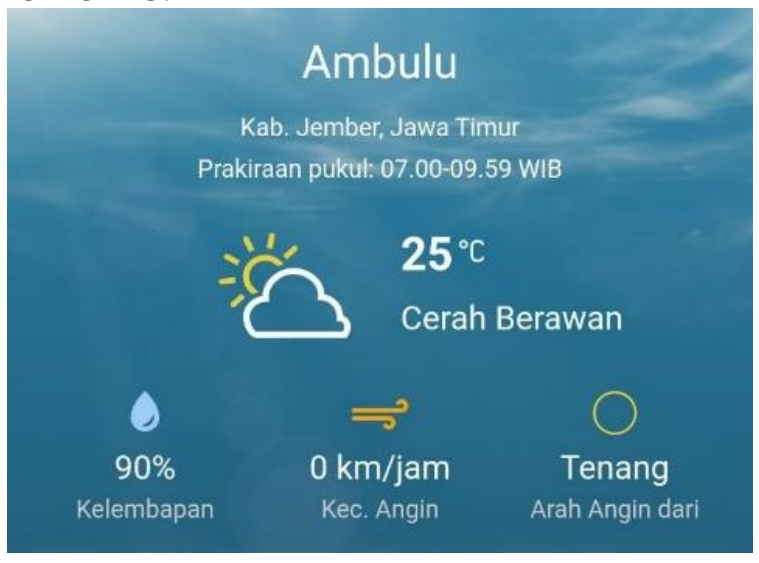

Gambar I. BMKG (Badan Meteorologi limatologi dan Geofisika)

Suhu merupakan suatu derajat panas pada sebuah objek. Sedangkan suhu udara yaitu memiliki arti ukuran panas atau dinginnya suatu permukaan bumi dan atmosfer bumi. Untuk keperluan operasional Klimatologi di Negara Indonesia, terutamaa bagi stasiun yang beroperasinya kurang dari 24 jam, maka suhu udara dalam permukaan rata-rata harian dapat dihitung dengan persamaan dibawah berikut ini:
Trata-rata $=\frac{2 \cdot \mathrm{T} 1+\mathrm{T} 2+\mathrm{T} 3}{4}$

\section{KETERANGAN :}

Trata-rata = rata rata suhu udara lingkungan harian $\left(^{\circ}\right)$

$\mathrm{T}_{1}=$ suhu udara pada pukul 07.00 LT

$\mathrm{T}_{2} \quad=$ suhu udara pada pukul 13.00 LT

$\mathrm{T}_{3} \quad=$ suhu udara pada pukul $8.00 \mathrm{LT}$

Keadaan suhu udara pada suatu tempat di permukaan bumi akan ditentukan oleh beberapa faktor faktor (Tanudidjaja, 1993) yakni sebagai berikut :

\section{a. Lamanya Penyinaran Matahari}

Semakin lama waktu yang digunakan matahari untuk memancarkan sinarnya disuatu daerah, maka akan semakin banyak panas yang diterima oleh daerah tersebut. Keadaan saat atmosfer cerah pada sepanjang hari hal itu akan menyebabkan keadaan lebih panas daripada keadaan atmosfer hari itu berawan sejak pagi.

b. Kemiringan Sinar Matahari

Selain dari lamanya penyinaran matahari, suhu udara juga di sebabkan oleh suatu tempat yang posisi matahari hari itu berada tegak lurus di atasnya, maka suatu radiasi matahari yang diberikan pada daerah tersebut akan lebih besar dan suhu ditempat tersebut akan semakin tinggi, dibandingkan dengan tempat yang posisi mataharinya lebih miring.

c. Keadaan Awan

Adaya awan di atmosfer akan menyebabkan berkurangnya suatu pancaran radiasi matahari yang akan diterima oleh permukaan bumi. Karena suatu pancaran radiasi yang mengenai pada awan, oleh uap air yang ada di dalam awan tersebut akan dipencarkan, dipantulkan, dan diserap.

\section{d. Keadaan Permukaan Bumi}

Keadaan permukaan bumi ini ada dua sifat yaitu sifat darat dan sifat laut dari kedua sifat ini yang akan mempengaruhi pada proses penyerapan dan pemantulan radiasi matahari ke permukaan bumi. Permukaan darat akan lebih 
cepat dalam proses menerima dan melepaskan suatu panas energy radiasi matahari yang diterima oleh permukaan bumi dan akibatnya yaitu dapat menyebabkan perbedaan suhu udara di atasnya, tetapi juga dipengaruhi oleh cahaya terhadap waktu yang di lalui. (Fadholi, 2016)

Kelembapan udara merupakan suatu keadaan yang dalam udara atau atmosfer tersebut mengandung suatu uap air. Besarnya kelembapan udara bergantung pada masuknya uap air ke dalam atmosfer karena adanya penguapan dari air yang ada di lautan, muara, dan sungai, maupun dari air di dalam tanah. Disamping itu terjadi juga dari proses transpirasi, yaitu penguapan dari tumbuh tumbuhan. Sedangkan banyaknya air di dalam udara bergantung pada beberapa faktor, antara lain ketersediaan air, sumber uap, suhu udara, tekanan udara, dan angin, jika ada beberapa yang tidak tersedia maka kelembapan udara akan rendah. Uap air dalam atmosfer dapat berubah ubah bentuknya dapat menjadi cair ataupun padat yang akan jatuh ke bumi biasa kita sebut sebagai hujan, jadi proses terjadinya hujan yaitu terkumpulnya uap air didalam atmosfer yang akan berubah bentuk. Kelembapan udara yang cukup besar menunjukkan bahwa di udara banyak mengandung uap air atau bisa kita kenal bahwa udara tersebut bersifat atau dalam keadaan basah (Fadholi, 2016).

Cuaca dan iklim memiliki beberapa unsur-unsurnya seperti: hujan, angin, cerah, berawan, temperatur, tekanan udara dan lainlain. Cuaca ini dapat dipengaruhi oleh beberapa faktor seperti pada cara kerja lima pengatur (regime) yaitu pada atmosfer, biosfer, hidrosfer, kriosfer dan pedosfer. Suhu udara merupakan suatu tingkatan derajat panas unsur cuaca dasar yang akan menunjukkan hasil yang bervariasi lumayan besar yang diakibatkan oleh insolasi geografis yang tidak tersebar merata. Kelembapan udara merupakan banyaknya kadar uap air yang terkandung di udara, semakin besar kelembapan udaranya maka semakin besar kesempatan terjadinya penurunan hujan (Ginting et al, 2012).

\section{METODE}

Metode penelitian yang dilakukan untuk mengumpulkan data yaitu dilakukan secara langsung atau metode surve. Sebelum melakukan penelitian ada beberapa faktor yang harus dilakukan yaitu menetukan tempat yang ingin di buat penelitian, alat alat yang digunakan untuk penelitian, melakukan penelitian, dan yang terakhir pengambilan data yang ingin diteliti. Gambaran metode penelitian yang akan dilakukan dapat dilihat pada gambar 2 .

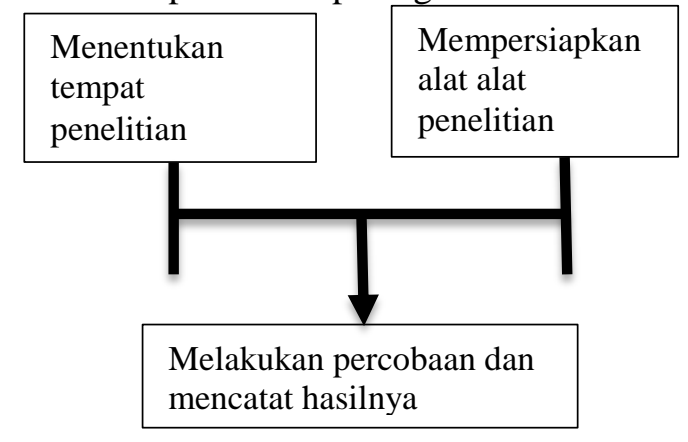

\section{Gambar 2. Prosedur Penelitian}

Penelitian yang dilakukan pada semester genap tahun ajaran 2020/2021 dilaksanakan di Desa Karanganyar Kecamatan Ambulu Kabupaten Jember untuk mengukur suatu besar suhu lingkungan, kelembapan udara dan intensitas cahaya matahari pada 4 hari. Pengambilan data pada penelitian dilakukan setiap 2 jam sekali mulai pada pukul 05.00 AM - 23.00 PM. Adapun alat yang digunakan dalam proses penelitian ini yaitu mengunakan aplikasi BMKG (Badan Meteorologi Klimatologi dan Geofisika) untuk mendapatkan hasil yang akurat.

Alasan melakukan penelitian ini yaitu sebagai tugas ujian akhir semester genap tahun ajaran 2020/2021. Selain itu juga menambah wawasan mengenai ilmu tentang alam yang masih behubungan langsung dengan pelajaran fisika.

Tujuan saya melakukan penelitian ini yaitu untuk memenuhi tugas akhir pada mata kuliah Fisika Lingkungan. Menambah wawasan kepada peneliti tentang ilmu alam.

\section{HASIL PENELITIAN DAN PEMBAHASAN}

Hasil yang diperoleh pada penelitian ini yaitu semakin siang makan suhu udara nya semakin panas tetapi pada saat pukul 15.00 23.00 suhu udara mulai menurun kembali. Sedangkan pada kelembapan udara semakin 
siang maka semakin kecil kelembapan udaranya. karena, kadar air yang tersimpan di udara di pengaruhi oleh intensitas cahaya matahari semakin cerah cahaya mataharinya maka semakin kecil kelembapan udaranya.

Tabel 1. Hasil pengukuran suhu

\begin{tabular}{ccccc}
\hline \multirow{2}{*}{ WAKTU } & \multicolumn{4}{c}{ TEMPERATUR (C) } \\
\cline { 2 - 5 } & 28 -Mar & 30 -Mar & TANGAL & 03-Apr \\
\cline { 2 - 5 } & 22 & 22 & 23 & 22 \\
05.00 & 25 & 23 & 24 & 25 \\
09.00 & 27 & 28 & 27 & 27 \\
11.00 & 28 & 29 & 28 & 28 \\
13.00 & 31 & 27 & 31 & 30 \\
15.00 & 27 & 23 & 24 & 25 \\
17.00 & 25 & 23 & 25 & 26 \\
19.00 & 24 & 25 & 23 & 23 \\
21.00 & 23 & 24 & 23 & 23 \\
23.00 & 24 & 23 & 24 & 23 \\
\hline
\end{tabular}

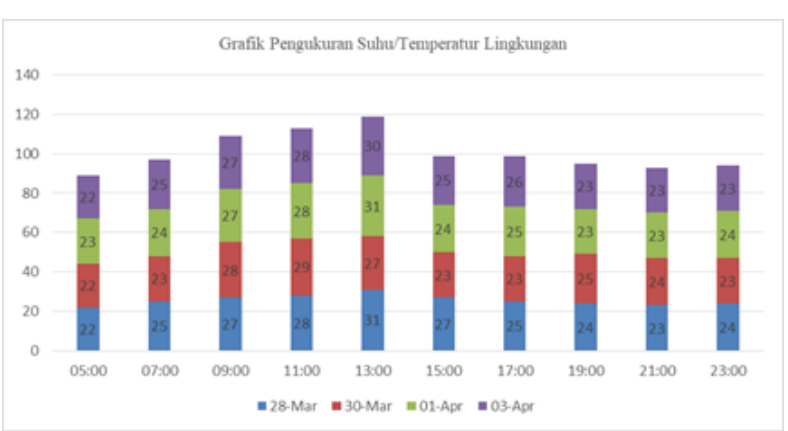

Gambar 3. Grafik Pengukuran Suhu

Pengukuran temperatur atau suhu lingkungan yang dilakukan di Desa Karanganyar dengan menggunakan aplikasi $B M K G$ ini memang tidak sedikit akurat tetapi untuk hasil dan kondisi aslinya tidaklah jauh beda. Dari data yang diperoleh seperti pada grafik di atas menunjukkan bahwa semakin siang maka suhu lingkungannya juga semakin besar. Karena semakin siang suasana nya semakin panas dan hal ini yang mengakibatkan suhu udara semakin siang semain besar. Tetapi bisa terjadi juga semakin siang suhunya semakin rendah hal ini di sebabkan karena cuaca yang tejadi tidak seperti biasanya, bisa jadi pada hari itu juga cuacanya mendung dan mengakibatkan suhu udaranya rendah. Hasil yang di dapatkan pada saat pukul 05.00 AM suhu lingkungan masih sangat rendah yaitu $22^{\circ} \mathrm{C}$, tetapi semakin lama maka semakin tinggi pada saat pukul 12.00 AM suhunya mencapai $30^{\circ} \mathrm{C}-31^{\circ} \mathrm{C}$. Akan tetapi pada saat pukul 15.00 PM suhu lingkungan mulai menurun sampai dengan pukul 23.00 PM. Pada penelitian hari kedua suhu udara pada saat pukul 13.00 suhu udaranya mencapai $27{ }^{0} \mathrm{C}$ yang biasanya suhu normal pukul 13.00 yaitu $30^{\circ} \mathrm{C}-31^{\circ} \mathrm{C}$, pada hari itu terjadi hujan ringan maka mengakibatkan suhu tidak sesuai dengan suhu normal setiap jam nya. 
Karst : Jurnal Pendidikan Fisika dan Terapannya Volume 4 | Nomor 1 | 31 p-ISSN: 2622-9641 e-ISSN: 2655-1276

Tabel 2. Pengukuran kelembapan udara

\begin{tabular}{|c|c|c|c|c|}
\hline \multirow{3}{*}{ WAKTU } & \multicolumn{4}{|c|}{ KELEMBAPAN UDARA (100\%) } \\
\hline & \multicolumn{4}{|c|}{ TANGGAL } \\
\hline & 28-Mar & 30-Mar & 01-Apr & 03-Apr \\
\hline 05.00 & 100 & 90 & 100 & 95 \\
\hline 07.00 & 90 & 100 & 100 & 90 \\
\hline 09.00 & 75 & 85 & 80 & 85 \\
\hline 11.00 & 28 & 85 & 85 & 75 \\
\hline 13.00 & 65 & 90 & 65 & 70 \\
\hline 15.00 & 70 & 100 & 95 & 90 \\
\hline 17.00 & 90 & 100 & 80 & 85 \\
\hline 19.00 & 90 & 95 & 100 & 95 \\
\hline 21.00 & 95 & 100 & 100 & 95 \\
\hline 23.00 & 95 & 95 & 95 & 100 \\
\hline
\end{tabular}

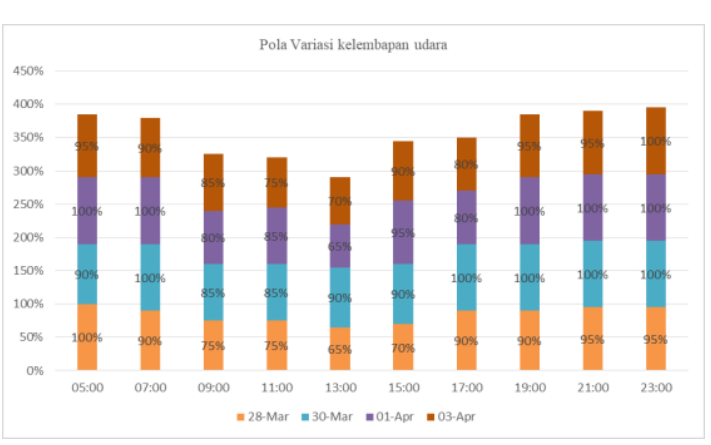

Gambar 4. Grafik Kelembapan Udara

Dari hasil pengukuran kelembapan udara ini menunjukkan bahwa semakin lembab udaranya maka semakin besar nilai kelembapan udara tersebut. Dari kelembapan udara ini dapat mendeteksi kadar air yang terdapat di udara, dan bisa juga mengakibatkan turunnya hujan. Dari hasil yang diperoleh seperti pada grafik di atas yaitu pada saat masih pagi kelembapan udaranya sangat besar karena kadar air di udara masih sangat banyak tetapi semakin siang kelembapan udaranya semakin rendah. Pada saat pukul 05.00 kelembapan udaranya mencapai $90 \%$ - 100\% tepai saat pukul 13.00 kelembapan udara $65 \%$ $70 \%$ tetapi pada saat penelitian hari ke dua kelembapan udaranya mencapai $90 \%$ hal ini terjadinya hujan ringan jadi yang harusnya kelemabapan udara sekitar $65 \%$ - $70 \%$ pada hari itu mencapai $100 \%$.

Tabel 3. Pengukuran perkiraan cuaca

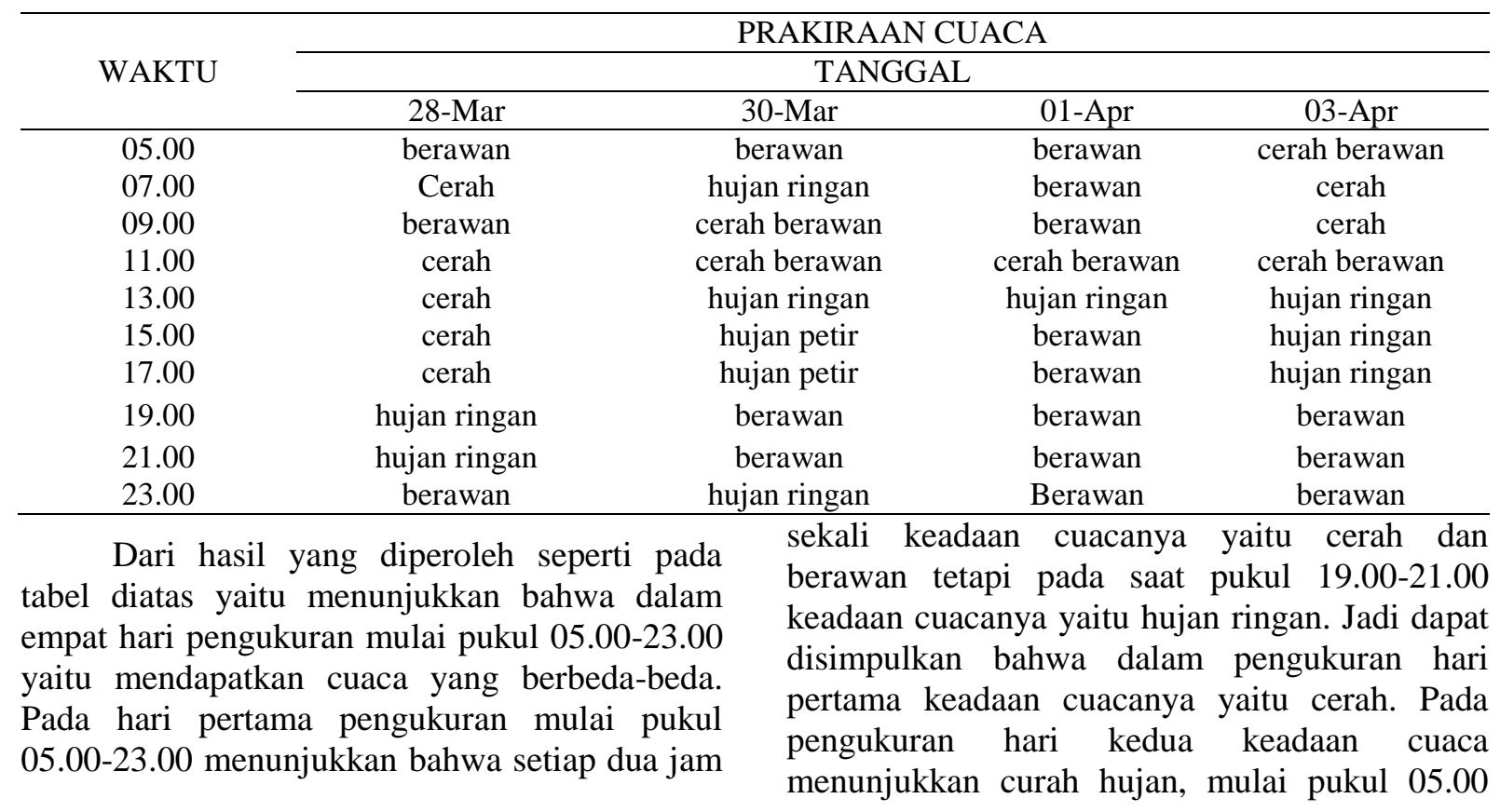


keadaan cuaca mendung dan pada pukul 07.00 hingga pukul 23.00 terjadi penurunan hujan. Pengamatan hari ketiga menunjukkan cuaca mendung mulai pagi hingga malam, dan terjadi hujan ringan pada saat pukul 13.00. Pengamatan hari terakhir menunjukkan cuaca cerah tetapi juga mendung dan sampai terjadi penurunan hujan.

\section{PENUTUP}

Berdasarkan hasil dan pembahasan yang sudah di sajikan diatas dapat disimpulkan bahwa

\section{DAFTAR PUSTAKA}

Depari, C. N., Irsal, I., \& Ginting, J. 2015. Pengaruh Curah Hujan dan Hari Hujan terhadap Produksi Kelapa Sawit Berumur 12, 15, 18 Tahun di PTPN II Unit Sawit SeberangBabalan Kecamatan Sawit Seberang Kabupaten Langkat. Jurnal Online Agroekoteknologi, 3 (1): 299-309.

Fadholi, A. 2016. Pemanfaatan Suhu Udara Dan Kelembapan Udara Dalam Persamaan Regresi Untuk Simulasi Prediksi Total Hujan Bulanan Di Pangkalpinang. AdMathEdu : Jurnal Ilmiah Pendidikan Matematika, Ilmu Matematika dan Matematika Terapan, 3(1). https://doi.org/10.12928/admathedu.v3i1.4828

Pongtuluran, Y. 2015. Manajemen Sumber Daya Alam dan Lingkungan. Yogyakarta : CV Andi Offset.

Prasetyo, L. H. 2012. Teknologi peternakan dan veteriner untuk peningkatan produksi dan antisipatif terhadap dampak perubahan iklim, ada hubungan antara suhu udara, kelembapan udara dan indeks kecerahan terhadap cuaca. Semakin besar suhu udara maka semakin rendah kelembapan udara nya, hal ini juga dilihat dari waktu pengamatan. Jika pada saat pengamatan pukul 13.00 PM dan suhu udara menunjukkan sebesar $27^{\circ} \mathrm{C}$ sedangkan kelembapan udaranya menunjukkan $90 \%$ hal ini dapat di prediksi bahwa keadaan cuacanya yaitu mendung bahkan bisa saja terjadinya penurunan hujan dan indeks kecerahannya yaitu gelap, karena pada saat pukul 13.00 AM suhu normal pada lingkungan yaitu berkirasr sebesar $31^{\circ} \mathrm{C}-33^{\circ} \mathrm{C}$.

Prosiding Seminar Nasional Teknologi Peternakan dan Veteriner: Bogor, 7-8 Juni 2011. IAARD Press.

Purba, Z. 2018. Regresi Linier Berganda Kelembaban Udara Dan Intensitas Cahaya Matahari Terhadap Produksi Tanaman Padi Di Perkotaan. 6.

Simanjuntak, L. N., \& Sipayung, R. 2014. Pengaruh Curah Hujan Dan Hari Hujan Terhadap Produksi Kelapa Sawit Berumur 5, 10 Dan 15 Tahun Di Kebun Begerpang Estate Pt.Pp London Sumatra Indonesia, Tbk. 2337, 11.

Tampubolon, K., \& Sihombing, F. N. 2017. Pengaruh Curah Hujan Dan Hari Hujan Terhadap Produksi Pertanian Serta Hubungannya Dengan Pdrb Atas Harga Berlaku Di Kota Medan. 5, 35-41.

Utoyo, B. 2007. Geografi: Membuka Cakrawala Dunia. PT Grafindo Media Pratama. 